\title{
Suitable Sowing Rate for Peas and Beans - A Review
}

\author{
Margit Olle* \\ Department of agriculture, Estonian Crop Research Institute, Estonia
}

Submission: January 22, 2018.; Published: March 13, 2018

"Corresponding author: Margit Olle, Estonian Crop Research Institute, J Aamissepa 1, Jogeva alevik, 48309, Estonia, Email: margit.olle@gmail.com

\begin{abstract}
The purpose of this investigation was to find suitable sowing rates for peas and beans according to literature review. The sowing rate of faba beans depends on 100 seed weight (grams), target plant population, establishment percentage and germination percentage. Optimum plant populations for most faba beans can range from 20 to 35 plants per square metre. For the medium to larger sized faba beans (Manafest, Icarus) and the small broadbeans, optimum plant populations can vary from 15 to 25 plants per square metre. For larger broadbeans, optimum plant populations can vary from 8 to 12 plants per square metre. Field peas sowing rate should be around 100 seeds per $\mathrm{m}^{2}$. The reasons for that are followed: Plant stands of less than about 100 plants $\mathrm{m}^{-2}$ always reduced pea seed yield in weedy conditions, especially for semi-leafless upright pea cultivars are grown and optimal weed control is not possible. Increasing seed rates above 100 plants $\mathrm{m}^{-2}$ caused decrease in seeds per pod and seed crude protein yield. An unfortune was that increasing seed rates above 100 plants $\mathrm{m}^{-2}$ increased also lodging scores.
\end{abstract}

Keywords: Faba bean; Field pea; Sowing rate; Smooth peas

\section{Introduction}

In Europe field pea is widely cultivated [1]. Field peas are also known as smooth peas or specifically green and yellow cotyledon dry peas [2]. It is an herbaceous annual crop in the Fabaceae (formerly Leguminosae) family. The Mediterranean basin and the Near East are the places from where pea crop originates. Nowadays it is widely grown for its seedpod. Pea is an important human food crop [1].

Among various grain legume crops grown in Europe, faba bean ranks presently second in area and production after pea and before lupins, soya, chickpeas and lentils. China is the main producer of faba bean in the world with $39 \%$ of the total world production. Then, the major producers in order of importance are United Kingdom, Ethiopia, Egypt and France. Cultivated faba bean is mainly used as human food in developing countries and as animal feed for pigs, horses, poultry and pigeons in industrialized countries [3].

Field peas and faba beans are important crops due to their protein content. The protein content of field peas may vary as followed: $21.4-23.9 \%$ [4], 20.5-22.1\% [5], 15.8-32.1\% [6], 21.9$34.4 \%$ [7], 15.8-32.1\% [8], 20.6-27.3\% [9], 24-32.4\% [10,11], $18.3-31 \%$ [12]. [13] Found that the protein content for the nineteen pea genotypes ranged from 21.13 to $27.05 \%$, with a mean of $23.89 \%$ and stated that these differences in protein content were due to a combination of genetic and environmental factors. The protein content of faba beans ranges from $20 \%$ to $41 \%$, values which depend on the variety [13].
Sowing rate of field peas is affected by environmental factors such as rainfall, irrigation, or soil type, as the more favourable the environment, the higher will be the optimum population [14]. Seeding rates for faba bean vary according to seed size, sowing time and region [15].

The purpose of this investigation was to give the literature overview about field peas and faba beans suitable sowing rates.

\section{Discussion Faba Bean And Sowing Rate}

[15] is describing the method how to calculate right sowing rate:

100 seed weight (grams) $\times$ target plant population $\times 1000$ $\div$ establishment percentage $*$ germination percentage $=$ your seeding rate $\mathrm{kg} / \mathrm{ha}$.

(* Establishment percentage - $90 \%$ is a reasonable estimate, unless sowing into adverse conditions).

Seeding rates for faba bean vary according to seed size, sowing time and region [15].

[16] gave some advices on sowing rates of faba beans:

i. Optimum plant populations for most faba beans can range from 20 to 35 plants per square metre.

ii. For the medium to larger sized faba beans (Manafest, Icarus) and the small broadbeans, optimum plant populations can vary from 15 to 25 plants per square metre 
iii. For larger broadbeans, optimum plant populations can vary from 8 to 12 plants per square metre.

iv. Sowing at the lower plant population range sometimes reduces the risk of foliar disease, as the crop is usually less bulky.

v. Seeding rates resulting in lower than recommended plant populations could reduce potential crop yields.

[17] suggested that the plant population of 12.5 plants $\mathrm{m}-2$ was found to be optimum in the second growing season, whereas 25 plants $\mathrm{m}-2$ was considered the proper population where chilling injury and drought were prevailing. Due to unpredictable environmental conditions a planting density of 25 plants $\mathrm{m}-2$ should be used. Further increase of population will have no economical return on the produced yield.

At the same time [18] used 4 seeding rates (50\%, 75\%, 100\% and $125 \%$ ) and conluded that The $50 \%$ seeding rate resulted in significantly lower yield and total dry matter, but the highest seed weight and the greatest number of pods per plant, as well as the greatest number of days to maturity. The $75 \%, 100 \%$ and $125 \%$ seeding rates resulted in equivalent yield and total dry matter, but significantly fewer pods per plant and reduced seed weight as seeding rate increased. Increased seeding rate partially compensated for delayed seeding. Seeding as early as possible at $75 \%$ of the present recommended seeding rate of 46 plants $\mathrm{m} 2$ should maximize return on seeding cost to the grower.

[19] found that high sowing rates (the sowing rate range was 70 - 270kg ha-1) produced tall crops with the lowest pods further from the soil surface than those at low plant density, and hence, mechanical harvesting was easier. The same authors concluded based on literature review that the influences of high sowing rate were:

i. Faba bean yield increase with plant population increase, while the number of pods per plant decreased.

ii. Greater leaf area, radiation absorption and greater dry matter production of faba bean.

iii. Earlier canopy closure of faba bean, which may cause greater supression of weeds and aphids and reduced evaporation from soil.

iv. Faba beans can yield well over a wide range of plant populations under favourable conditions as they have the ability to compensate and fill in plant rows [15].

\section{Conclusion}

It must be concluded that the sowing rate depends on 100 seed weight (grams), target plant population, establishment percentage and germination percentage. Optimum plant populations for most faba beans can range from 20 to 35 plants per square metre. For the medium to larger sized faba beans (Manafest, Icarus) and the small broadbeans, optimum plant populations can vary from 15 to 25 plants per square metre. For larger broadbeans, optimum plant populations can vary from 8 to 12 plants per square metre.

\section{Discussion Field Pea and Sowing Rate}

[20] in their study had four varieties with contrasting morphology and six seeding rates ranging from 25 to 90 viable seeds $/ \mathrm{m} 2$, increasing seeding rate increased seedling density and seed yield. Similarily [21] described that one study determined that plant stands of less than about 100 plants $\mathrm{m}^{-2}$ always reduced pea seed yield in weedy conditions, especially for semi-leafless upright pea cultivars are grown and optimal weed control is not possible. At the same time [22] based on their trial and previously published work made followed conclusions. Without irrigation, 70 plants $/ \mathrm{m}$ would seem to be optimum on shallow soils increasing to 90 plants $\mathrm{m} 2$ on deeper soils. With irrigation these densities can increased to 120-130 plant $\mathrm{m} 2$ particularly if the crop is harvested green for processing. Row width should be $15 \mathrm{~cm}$ or less if drills will allow narrower sowings. For garden peas which branch freely these rates may well be lower but further research is required on this aspect.

However [23] used followed seed rates: 75, 100, 125 and 150 seeds per $\mathrm{m} 2$. They found that increasing seed rates resulted in an increase in plants per $\mathrm{m} 2$, forage yield, dry matter yield and forage crude protein yield. While, increasing seed rates caused decrease in seeds per pod and seed crude protein yield. An unfortune was that increasing seed rates increased also lodging scores.

Pea plants compensated for low plant populations by producing more pods per plant and more seeds per pod although this compensation mechanism was not enough to maintain high yield at low populations in all environments. Seeding rates that gave best partial net economic returns varied from year to year, but with a trend for lower returns at seeding rates greater than 77 seeds/m2 [20]. In addition [24] concluded that when intrarow spacing is increased branching increases.

Therefore the recommended sowing rates for maple, blue and white peas vary considerably, according to variety and seed size. The ability of some varieties to produce pod-bearing branches from basal positions may enable them to be drilled at lower rates without significantly depressing yield. In addition, the number of branches per plant has been found to increase with a decrease in population [24].

[24] described that sowing rate also is affected by environmental factors such as rainfall, irrigation, or soil type, as the more favourable the environment, the higher will be the optimum population. Higher plant densities are more likely to suppress weed growth and this was obvious in their research.

\section{Conclusion}

Seed rate should be around 100 seeds per $\mathrm{m} 2$. The reasons for that are followed: 
i. Plant stands of less than about 100 plants $\mathrm{m}^{-2}$ always reduced pea seed yield in weedy conditions, especially for semi-leafless upright pea cultivars are grown and optimal weed control is not possible.

ii. Increasing seed rates above 100 plants $\mathrm{m}^{-2}$ caused decrease in seeds per pod and seed crude protein yield.

iii. An unfortune was that increasing seed rates above 100 plants $\mathrm{m}^{-2}$ increased also lodging scores.

\section{Acknowledgement}

This investigation has been developed with the help of the project EUROLEGUME, funded from the European Union Seventh Framework Programme for Research, Technological Development and Demonstration under the grant agreement No. 613781.

\section{References}

1. Olle M, Narits L, Williams IH (2015) The influence of variety on the yield and content of protein and nutrients of peas (Pisum sativum) In: Annual $21^{\text {st }}$ International Scientific Conference Research for Rural Development. Latvia University of Agriculture, Latvia.

2. Dahl WJ, Foster JM, Tyler RT (2012) Review of the health benefits of peas (Pisum sativum L.). British Journal of Nutrition 108(Suppl 1): S3S10.

3. Feverole G (2004) Vicia Faba breeding for sustainable agriculture in EUROPE. D7: WP 1- EUFABA, pp. 29.

4. Saastamoinen M, Eurola M, Hietaniemi V (2013) The Chemical Quality of Some Legumes, Peas, Fava Beans, Blue and White Lupins and Soybeans Cultivated in Finland. Journal of Agricultural Science and Technology B3: 92-100.

5. Jabeen T, Iqbal P, Khalil IA (1988) Amino acid and mineral composition of pea cultivars grown in Peshawar. Pakistan J Agric Res 9(2): 171-175.

6. Pratap A (2011) Biology and breeding of food legumes. Indian Institute of Pulses Research pp. 432.

7. Bastianelli D, Grosjean F, Peyronnet C, Duparque M, Régnier JM (1998) Feeding value of pea (Pisum sativum L.) Chemical composition of different categories of pea. Animal Science 67: 609-619.

8. Blixt S (1978) Problems relating to pea breeding. Agri Hortique Genetica 36: 56-87.

9. Burstin J, Marget P, Huart M, Moessner A, Mangin B, et al. (2007) Developmental genes have pleiotropic effects on plant morphology and source capacity, eventually impacting on seed protein content and productivity in pea. Plant Physiology 144: 768-781.

10. Gabriel I, Lessire M, Juin H, Burstin J, Duc G, et al. (2008) Variation in seed protein digestion of different pea (Pisum sativum L.) genotypes by cecectomized broiler chickens: 1 . endogenous amino acid losses, true digestibility and in vitro hydrolysis of proteins. Livestock Science 113: 251-261.

11. Gabriel I, Quillien L, Cassecuelle F, Marget P, Juin H, et al. (2008) Variation in seed protein digestion of different pea (Pisum sativum $L$ ) genotypes by cecectomized broiler chickens: 2 . Relation between in vivo protein digestibility and pea seed characteristics, and identification of resistant pea polypeptides. Livestock Science 113: 262-273.

12. Harmankaya M, Özcan MM, Karadas S, Ceuhan E (2010) Protein and mineral contents of pea (Pisum sativum L.) genotypes grown in Central Anatolian region of Turkey. South Western Journal of Horticulture, Biology and Environment 1(2): 159-165.

13. Vidal-Valverde C, Frias J, Sotomayor C, Diaz-Pollan C, Fernandez, et al. (1998) Nutrients and antinutritional factors in faba beans as affected by processing. Zeitschrift für Lebensmitteluntersuchung undForschung 207(2): 140-145.

14. Falloon PG, White JGH (1978) Effect of plant population on seed yield and yield components of field peas. Proceedings Agronomy Society of New Zealand 8: 27-30.

15. Anonymous (1997) Winter crop variety showing guide 2015, Australia region NSW DPI Management Guide.

16. Hawthorne W (2004) Faba Bean Disease Management Strategy for Southern Region GRDC. Pulse Australia.

17. Al-Rifaee M, Turk MA, Tawaha ARM (2004) Effect of Seed Size and Plant Population Density on Yield and Yield Components of Local Faba Bean (Vicia faba L. Major). Int J Agri Biol 6(2): 294-299.

18. Mc Vettey PBE, Evans LE, Nugent-Rigby J (1986) Response of faba beans (Viciafaba L.) to seeding date and seeding rate. Can J Plant Sci 66: 39-44.

19. Loss SP, Siddique KHM, Martin LD, Crombie A (1998) Responses of faba bean (Vicia faba L.) to sowing rate in south-western Australia II* Canopy development, radiation absorption and dry matter partitioning. Aust. J Agric Res 49(6): 999-1008.

20. Thandiwe N, Rickertsen J (2011) Seeding Rate and Variety Effects on Yield, Yield Components, and Economic Return of Field Pea in the Northern Great Plains. Crop Management 10(1).

21. Johnston A M, Clayton GW, Lafond GP, Harker KN, Hogg TJ, et al. (2002) Field pea seeding management. Can J Plant Sci 82(4): 639-644.

22. White JGH, Sheath GW, Meijer G (1982) Yield of garden peas-field responses to variation in sowing rate and irrigation, New Zealand Journal of Experimental Agriculture 10(2): 155-160.

23. Türk M, Albayrak S, Yüksel O (2011) Effect of seeding rate on the forage yields and quality in pea cultivars of differing leaf types. Turkish Journal of Field Crops 16(2): 137-141.

24. Falloon PG, White JGH (1978) Effect of plant population on seed yield and yield components of field peas. Proceedings Agronomy Society of New Zealand 8: 27-30. 
@-

This work is licensed under Creative Commons Attribution 4.0 License

DOI: 10.19080/JOJHA.2018.01.555555
Your next submission with Juniper Publishers will reach you the below assets

- Quality Editorial service

- Swift Peer Review

- Reprints availability

- E-prints Service

- Manuscript Podcast for convenient understanding

- Global attainment for your research

- Manuscript accessibility in different formats

( Pdf, E-pub, Full Text, Audio)

- Unceasing customer service

Track the below URL for one-step submission https://juniperpublishers.com/online-submission.php 